\title{
THE APPLICATION OF KIND OF CLASSROOM TEACHING CONTEXTUAL LEARNING ( CTL) THROUGH THE USE OF GOOGLE CLASSROOM FOR A PANDEMIC COVID 19 ECONOMICS TEACHER IN HIGH SCHOOL STUDENTS TAMAN SISWA PADANG
}

\section{APLIKASI MODEL PEMBELARAN CONTEXTUAL TEACHING LEARNING (CTL) MELALUI PENGGUNAAN GOOGLE CLASSROOM SELAMA PANDEMI COVID 19 PADA GURU EKONOMI SMA TAMAN SISWA PADANG}

\author{
Stevani ${ }^{1}$, Vivina Eprillison, Meri Rahmania ${ }^{3}$, Yuli Diniah Zulbakri ${ }^{4}$ \\ Prodi Pendidikan Ekonomi STKIP PGRI Sumatera Barat, 25173 \\ Email: Stevani060390@gmail.com
}

\begin{abstract}
One of the media learning and an evaluation tool required teachers in the pendemi covid 19 this is google application that can be used classroom teachers in free in the learning process in the tissues .Google is a series of classroom produktivtas tools from google gmail are free, drive, and docs, made available to users google apps for education .Designed to help teachers or classroom teachers make and collect duty without using paper, including a feature to save time teachers like the ability to make a copy google docs automatically for each student .Classroom can also make folder drive for any task and each student, that they were still regularly. The desire to achieve in doing this is to provide humbling experience for teachers in using google online class which is very useful in the classroom covid 19 this pandemic
\end{abstract}

Key words: Entrepreneurial Soul, Creativity, and Dried Flowers.

\section{ABSTRAK}

Salah satu pemanfaatan media pembelajaran dan alat evaluasi yang diperlukan guru dalam masa pendemi covid 19 ini adalah aplikasi google classroom yang dapat dimanfaatkan guru secara gratis dalam proses pembelajaran dalam jaringan. Google Classroom adalah serangkaian tools produktivtas gratis dari Google meliputi Gmail, Drive, dan Docs, tersedia untuk pengguna Google Apps for Education. Classroom dirancang untuk membantu guru atau pengajar membuat dan mengumpulkan tugas tanpa menggunakan kertas, termasuk fitur untuk menghemat waktu Guru seperti kemampuan untuk membuat salinan Google Docs secara otomatis bagi setiap siswa. Classroom juga dapat membuat folder Drive untuk setiap tugas dan setiap siswa, agar semuanya tetap teratur. Tujuan yang hendak dicapai dalam melakukan kegiatan ini adalah untuk memberikan pengalaman berharga bagi guru dalam menggunakan kelas daring google classroom yang sangat bermanfaat dalam masa pandemi covid 19 ini.

Kata kunci: Masa Pandemi Covid 19, Media Pembelajaran, Google Classroom 


\section{Rangkiang: Lurnal Pengabdian Pada Masyarakat \\ UPSM STKIP PER/ Sumatera Barat}

ISSN: (2721-2688) Vol. 2 No 2 (Desember 2020): 101-106

\section{PENDAHULUAN}

Pendidikan merupakan proses interaksi antara pendidik dengan peserta didik untuk mencapai tujuan pendidikan yang sudah ditentukan. Pendidik, peserta didik, dan tujuan pendidikan merupakan komponen utama pendidikan, dalam hal ini jika salah satunya tidak ada, maka hilang pulalah hakikat pendidikan tersebut. Walaupun dalam situasi tertentu tugas guru, misalnya dapat diwakilkan atau dibantu oleh unsur lain seperti teknologi, namun fungsi guru sebenarnya tidak dapat tergantikan. Abuddin (2003:135) mengemukakan bawa keberhasilan, fungsi, dan tujuan pendidikan sangatlah ditentukan oleh para pendidik.

Peran guru secara keseluruhan disekolah menempati posisi utama

dalam mencapai tujuan pendidikan secara optimal. Berdasarkan PP No. 32 Pasal 19 tersebut sangat jelas bahwa untuk meningkatkan mutu pendidikan faktor guru memegang peranan yang sangat penting. Senada dengan hal itu Slameto (2010) mengemukakan guru memegang peranan yang sangat besar dalam pendidikan. Dalam proses pembelajaran di sekolah pendidik adalah orang yang berinteraksi langsung dengan peserta didik. Peningkatan mutu pendidikan ditentukan oleh kesiapan Sumber Daya Manusia yang terlibat dalam proses pendidikan dalam hal ini guru.

Keberhasilan penyelenggaraan pendidikan dan pengajaran di sekolah, tidak terlepas dari peranan dan dedikasi guru yang tinggi. Guru sebagai fasilitator harus mampu menjalankan tugas dan fungsinya dengan baik. Guru dituntut untuk dapat melaksanakan proses pembelajaran, evaluasi belajar, pemanfaatan media pembelajaran, penguasaan teknologi dan informasi.

Google Classroom (atau dalam bahasa Indonesia yaitu Ruang Kelas Google) adalah suatu serambi pembelajaran campuran yang diperuntukkan terhadap setiap ruang lingkup pendidikan yang dimaksudkan untuk menemukan jalan keluar atas kesulitan dalam membuat, membagikan dan menggolong-golongkan setiap penugasan tanpa kertas. Perangkat lunak ini telah diperkenalkan sebagai keistimewaan Google Apps for Education lalu itu disudahi dengan pengeluaran kepada khalayak sejak 12 Agustus 2014. Google sudah melakukan pemberitahuan mengenai antar muka pemprograman aplikasi dari sebuah ruang kelas dan sebuah tombol berbagi untuk situs web sehingga pihak kepengelolaan sekolah beserta para pengembang diperkenankan supaya melakukan penerapan lebih lanjut terhadap Google Classroom.

Pembelajaran berbasis teknologi informasi yang terangkum dalam Learning Managemen System (LMS), akan memberikan pengalaman terbaik bagi guru dan siswa saat melakukan KBM. Model pembelajaran seperti ini merupakan salah satu model pembelajaran inovatif berbasis e-learning. Tentunya mendukung adanya efisiensi waktu maupun kampanye paperless. Google Classroom bisa didapatkan secara gratis dengan terlebih dahulu mendaftarkan diri pada akun Google Application for Education. Anda dapat mendaftarkan diri secara gratis untuk Dapatkan Produk Google. Salah satunya adalah Google Classroom, Fasilitas e-mail dengan domain sendiri, Google Drive, dan lain-lain. Akun Google Aplikasi for Education ini sangat bermanfaat untuk pembelajaran secara online, dapat diperoleh secara gratis serta dapat digunakan untuk perangkat apa pun. Salah satu kecanggihan aplikasi ini adalah dapat digunakan secara bersama-sama dalam kelompok secara kolaboratif.

Pembelajaran berbasis teknologi informasi yang terangkum dalam Learning Managemen System (LMS), akan memberikan pengalaman terbaik bagi guru dan siswa saat melakukan KBM. Model pembelajaran seperti ini merupakan salah satu model pembelajaran inovatif berbasis e-learning. Tentunya mendukung adanya efisiensi waktu maupun kampanye paperless. 


\section{Rangkiang: Lurnal Pengabdian Pada Masyarakat UPSM STKIP PGR/ Sumatera Barat}

ISSN: (2721-2688) Vol. 2 No 2 (Desember 2020): 101-106

Google Classroom bisa didapatkan secara gratis dengan terlebih dahulu mendaftarkan diri pada akun Google Application for Education. Anda dapat mendaftarkan diri secara gratis untuk Dapatkan Produk Google. Salah satunya adalah Google Classroom, Fasilitas e-mail dengan domain sendiri, Google Drive, dan lain-lain. Akun Google Aplikasi for Education ini sangat bermanfaat untuk pembelajaran secara online, dapat diperoleh secara gratis serta dapat digunakan untuk perangkat apa pun. Salah satu kecanggihan aplikasi ini adalah dapat digunakan secara bersama-sama dalam kelompok secara kolaboratif.

Ada banyak Permasalahan yang dihadapi oleh guru SMA Taman Siswa Padang selama masa pandemi covid 19 , yang mana menharuskan guru dan murid melakukan pembelajran secara daring, diantaranya, 1) Sebagian guru disekolah mitra belum memahami dan menguasai google classroom sebagai alat pembelajaran yang efektif. 2) Kurangnya kesempatan yang dimiliki oleh guru untuk memperoleh hasil belajar siswa yang berkualitas pada masa pandemi covid 19 ini. 3) Kurangnya pemahaman guru dalam mengunakan pemanfaatan teknologi informasi pengunaan google classroom. 4) Kurangnya kemampuan guru dalam menganalisis pembelajaran secara online

Adapun tujuan yang ingin dicapai dalam kegiatan pengabdian pada masyarakat ini adalah 1) Guru memiliki kemampuan dalam penguasaan pembelajaran daring melalui program google classroom. Dengan kriteria pada akhir kegiatan minimal $80 \%$ dari materi pelatihan dapat dikuasai oleh guru SMA TAMAN SISWA Padang. 2) Guru dapat mengaplikasikan pengetahuan dalam aktifitas pelaksanaan belajar daring kepada siswa. Sebagai kriterianya adalah minimal $80 \%$ dari khalayak sasaran mampu mengaplikasikan program penggunaan google classroom dalam aktifitas mengajarnya. Sementara itu luaran yang diharapkan dalam pelaksanaan kegiatan pengabdian pada masyarakat ini adalah Publikasi artikel ilmiah yang diterbitkan dalam jurnal pengabdian dan Laporan kegiatan

\section{METODE PELAKSANAA KEGIATAN}

Metode pendekatan untuk mendukung program pengabdian pada masyarakat ini dilakukan dengan 1) Penulisan modul tentang penggunaan google classroom. 2) Penyajian materi sesuai dengan isi modul, 3) Pelatihan, workshop dan bimbingan individual terkait dengan penggunaan google classroom dalam pelaksanaan pembelajaran daring. Adapun prosedur kerja dalam pengabdian pada masyarakat ini adalah 1) Penulisan modul mengenai penggunaan google classroom dalam pembelajaran daring selama masa pandemi covid 19. 2 ) Penyajian materi sesuai dengan isi modul. Penyajian dilakukan dengan metode ceramah dibantu dengan media power point, dan diskusi. 3) Pelatihan dan bimbingan individual. Pelatihan difokuskan kepada guru untuk mempraktekkan atau mengimplementasikan cara penggunaa google classroom dalam proses pembelajaran. 


\section{Rangkiang: Lurnal Pengabdian Pada Masyarakat UPSM STKIP PER/ Sumatera Barat}

ISSN: (2721-2688) Vol. 2 No 2 (Desember 2020): 101-106

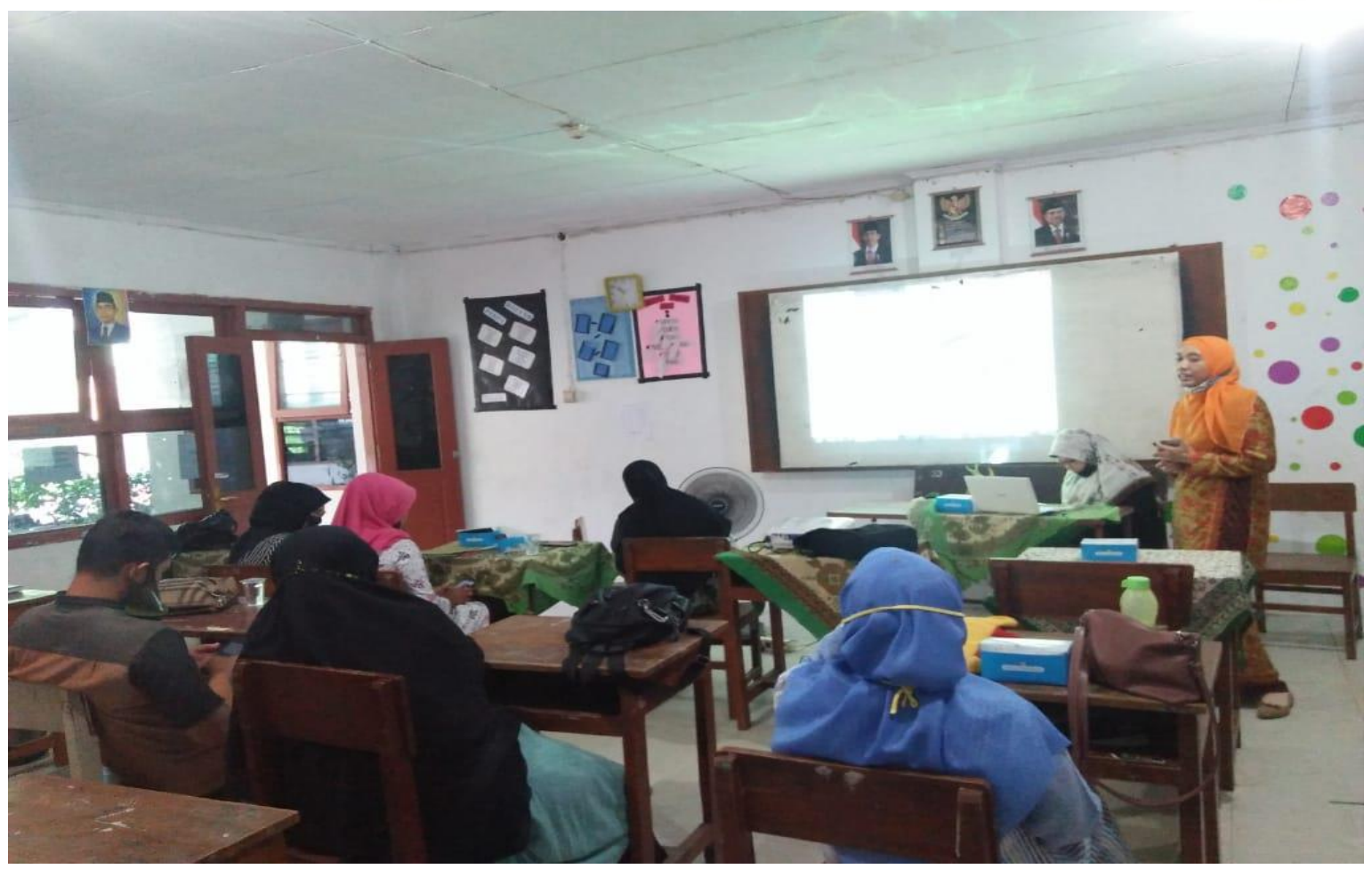

Gambar 1. Penyajian materi tentang Google Classroom

\section{HASIL DAN PEMBAHASAN}

Hasil kegiatan hasil dan pembahasan pelaksanaan program pengabdian Peningkatan Pemahaman Guru Mengenai penerapan penggunaan aplikasi google classroom dalam pelaksanaan pembelajaran daring pada masa covid 19 di SMA TAMAN SISWA Padang dapat dilihat dari luaran kegiatan ini yaitu: proses pelaksanaan pelatihan dan kemampuan guru untuk menerapkan program google classroom dalam proses pembelajaran pada masa pandemi covid 19. Kegiatan pertama yang dilakukan sebagai persiapan kegiatan ini adalah pemantapan jadwal yaitu penentuan jadwal konkrit bersama mitra setelah usulan kegiatan disetujui untuk dilaksanakan. Kegiatan selanjutnya yang dilakukan oleh tim yaitu melakukan pengurusan izin pelaksanaan kegiatan. Setelah perizinan selesai, maka dilakukanlah penetapan peserta bersama Kepala Sekolah Mitra. Total jumlah peserta yang dilibatkan dalam pelatihan direncanakan sebanyak 10 orang. Kegiatan ini dibagi menjadi beberapa tahapan, tahap pertama yaitu penyampaian materi oleh pembicara mengenai konsep program google classroom secara umum.Setiap selesai pemaparan materi oleh instruktur, dilakukan kegiatan diskusi dan tanya jawab seputar materi yang sudah disajikan oleh pembicara

Tahap selanjutnya yaitu penyampaian materi oleh pembicara mengenai panduan penerapan program google classroom dan disertai dengan contoh bagaimana penerapan google classroom dalam kegiatan pembelajaran.Setiap selesai pemaparan materi oleh instruktur, dilakukan kegiatan diskusi dan tanya jawab seputar materi yang sudah disajikan oleh pembicara Tahap selanjutnya adalah melakukan simulasi mengenai penerapan penggunaan program google classroom dalam kegiatan pembelajaran. Adapun simulasi mengenai penerapan program google classroom pada mata pelajaran ekonomi yang dilakukan membuat kelas pada google classroom serta membuat penugasan dengan aplikasi google classroom. Tahap akhir kegiatan Pada tahap ini dilakukan kegiatan observasi dan evaluasi. 


\section{Rangkiang: Lurnal Pengabdian Pada Masyarakat UPSM STKIP PER/ Sumatera Barat}

ISSN: (2721-2688) Vol. 2 No 2 (Desember 2020): 101-106

Evaluasi kegiatan program pengabdian ini diarahkan kepada tiga aspek kinerja yakni; aspek perencanaan, aspek pelaksanaan dan aspek hasil.

Pelatihan yang dilakukan bagi guru-guru SMA TAMAN SISWA Padang ini merupakan salah satu cara untuk meningkatkan kompetensi guru dalam menerapkan bagaimana mengevaluasi pembelajaran siswa sehingga dalam proses pembelajaran yang dapat meningkatkan motivasi dan hasil belajar siswa. Seiring dengan berbagai perkembangan yang terjadi guru dituntut harus dapat mengembangkan dan menerapkan pembelajaran bermakna yang dapat dipahami siswa dan dapat diterapkan dalam kehidupan sehari-hari.

Keunggulan software ini sebagai program pembelajaran daring jarak jauh dari pada Program lain adalah dapat digunakan untuk pelaksanaan ujian dengan butir soal bentuk uraian, di samping untuk juga bisa melaksanakan ujian soal bentuk pilihan ganda. Penggunaan bahasa Indonesia dalam program ini, juga merupa-kan salah satu sisi kemudahan dalam penggunaannya daripada program lain yang menggunakan bahasa Inggris. Hasil analisis tentang skor yang diperoleh setiap testee juga dapat ditransfer ke MsExcel untuk dihitung nilainya, maka saat mendalami program ini agar sekaligus dapat mendalami aplikasi MsExcel.

Ada beberapa keuntungan yang kita dapatkan dari Cara Kerja Google Classroom dalam pemanfaatannya sebagai Learning Management System (LMS), yakni 1) Proses setting yang cepat dan nyaman, Proses set up pada Google Classroom sangat cepat dan nyaman jika dibandingkan harus menginstall LMS lokal atau mendaftarkan ke provider LMS. Guru tinggal mengakses aplikasi Google Classroom serta bisa memulai membagikan tugastugas dan bahan ajar. 2) Hemat waktu, Peserta didik tidak lagi harus men-download tugas yang diberikan guru. Guru pun tinggal membuat dan mendistribusikan dokumen untuk peserta didik mereka secara online. Guru juga dapat menentukan peringkat, memberikan umpan balik untuk semua tugas dan melakukan penilaian menggunakan aplikasi Google Classroom. 3) Meningkatkan kerjasama dan komunikasi, Salah satu manfaat paling penting dari menggunakan Google Classroom adalah sangat dimungkinkan untuk melakukan kolaborasi online yang efisien. Guru dapat mengirimkan pemberitahuan ke peserta didik mereka untuk memulai diskusi online atau memberitahu mereka tentang kegiatan pembelajaran online tertentu. 4) Penyimpanan data terpusat, Dengan Google Classroom, semuanya berada dalam satu lokasi terpusat. Peserta didik dapat melihat semua tugas-tugas mereka dalam folder tertentu, guru dapat menyimpan bahan eLearning dan kegiatan untuk tahun ajaran secara cloud dan semua peringkat / nilai dapat dilihat dalam aplikasi. 5) . Berbagi sumber daya yang cepat, Fasilitator online/guru dan pelatih memiliki kekuatan untuk berbagi informasi dan sumber daya online dengan peserta didik mereka langsung. Daripada harus memperbarui kursus eLearning atau mengirim email individu untuk setiap siswa, mereka tinggal mengakses aplikasi Google Classroom dan mendistribusikan link ke sumber daya online dan materi eLearning tambahan yang dapat menguntungkan peserta didik mereka

\section{SIMPULAN}

Berdasarkan kegiatan yang telah dilaksanakan, maka dapat disimpulkan beberapa hal sebagai berikut: 1. Kegiatan pengabdian kepada masyarakat dilakukan di SMA TAMAN SISWA Padang pada tanggal 18 Juli 2020 diikuti oleh semua guru yang berjumlah 10 orang. 2. Program ini sangat bermanfaat bagi guru-guru sekolah mitra, karena program ini bisa meningkatkan pengetahuan dan keterampilan para guru dalam kegiatan Pemebelajaran dengan menggunakan program google classroom khususnya pada masa pandemi covid 19 ini. 
3. Program Pengabdian yang telah dilaksanakan di sekolah mitra, yaitu SMA TAMAN SISWA Padang berjalan dengan baik tanpa ada hambatan yang berarti.

\section{DAFTAR PUSTAKA}

Abuddin Nata. 2003. Manajemen pendidikan: Mengatasi Kelemahan Pendidikan Islam di Indonesia. Bogor: Kencana.

Irianto, Agus. 2007. Statistik Konsep Dasar dan Aplikasinya. Jakarta: Kencana.

Kurniawati, Tri. (2013). Revitalisasi Peran LPTK Dalam Peningkatan Profesionalisme Guru. Prosiding Seminar Nasional Pendidikan Ekonomi UNP. ISBN 978-602-17129-0-0.

Slameto. 2003. Belajar dan Faktor-faktor yang Mempengaruhinya. Rineka Cipta: Jakarta

Peraturan Pemerintah Republik Indonesia Nomor 32 Tahun 2013 Tentang Perubahan Atas Peraturan Pemerintah Nomor 19 tahun 2005 Tentang Standar Nasional Pendidikan. 